\title{
Appropriateness of Endoscopic Procedures: A Prospective, Multicenter Study
}

\author{
Carina Leal $^{\mathrm{a}}$ Nuno Almeida ${ }^{\mathrm{b}, \mathrm{c}}$ Maria Silva $^{\mathrm{a}}$ Antonieta Santos $^{\mathrm{a}}$ \\ Helena Vasconcelos ${ }^{\mathrm{a}}$ Pedro Figueiredo ${ }^{\mathrm{b}, \mathrm{c}}$ \\ a Department of Gastroenterology, Centro Hospitalar de Leiria, Leiria, Portugal; b Department of Gastroenterology, \\ Centro Hospitalar Universitário de Coimbra, Coimbra, Portugal; ' ${ }^{C}$ Faculty of Medicine, University of Coimbra, \\ Coimbra, Portugal
}

\section{Keywords}

Gastrointestinal endoscopy · Appropriateness .

Open-access endoscopy $\cdot$ Indications $\cdot$ Overuse

\section{Abstract}

Introduction: Advances in endoscopy and open-access systems led to an increase in endoscopic procedures. However, overuse of endoscopy has been consistently reported. This study aims to assess the appropriateness of esophagogastroduodenoscopy (EGD) and colonoscopy referral in the private and public setting. Patients and Methods: We conducted a prospective, multicenter study at 2 public and 5 private endoscopy units. Patients scheduled for elective EGD or colonoscopy were enrolled. Clinical data and endoscopy findings were recorded. Appropriateness of endoscopy was defined according to the American Society for Gastrointestinal Endoscopy guidelines (for EGD) and the European Panel on Appropriateness of Gastrointestinal Endoscopy II (for colonoscopy). Results: Regarding EGD: 215 patients enrolled $(43.7 \%$ were males) with a mean age of $61.0 \pm 15.1$ years; $54.0 \%(n=116)$ were in public hospitals. Referral by a gastroenterologist was made for $34.9 \%(n=75)$. Appropriate indications were made for $62.3 \%(n=134)$ : $42.4 \%$ in private versus $79.3 \%$ in public endoscopy units (odds ratio [OR] 5.20; $95 \%$ confidence interval $[\mathrm{Cl}] 2.85-9.49 ; p<0.01$ ). Rate of appropriate EGD was $74.7 \%$ for gastroenterologist referral and $56.1 \%$ for other specialties (OR $2.31 ; 95 \% \mathrm{Cl} 1.24-4.28 ; p<$ 0.01 ). Diagnostic yield for relevant findings was $47.9 \%$. No association between indication appropriateness, gastroenterologist referral, and relevant endoscopic findings was found. Regarding colonoscopy: 287 patients enrolled (49.1\% were males) with a mean age of $60.4 \pm 14.4$ years; $48.1 \%$ ( $n=$ 138) were in public hospitals. Referral by a gastroenterologist was made for $20.6 \%(n=59)$. Appropriate indications were made for $70.0 \%(n=201): 53.0 \%$ in private vs. $88.4 \%$ in public endoscopy units (OR 6.75; 95\% Cl 3.66-12.47; $p<$ 0.01 ). Diagnostic yield was $57.1 \%$. Relevant endoscopic diagnosis was associated with indication: $63.2 \%$ in the appropriate vs. $43.0 \%$ in the nonappropriate indication group $(p<$ 0.05). Discussion: A significant percentage of endoscopies, mainly in the private setting, were performed without an appropriate indication. This influenced the diagnostic yield. The use of adequate criteria is fundamental for the rational use of an open-access system. (c) 2021 Sociedade Portuguesa de Gastrenterologia
Published by S. Karger AG, Basel karger@karger.com www.karger.com/pjg

Karger"

GOPEN ACCESS
(C) 2021 Sociedade Portuguesa de Gastrenterologia. Published by S. Karger AG, Basel

This is an Open Access article licensed under the Creative Commons Attribution-NonCommercial-4.0 International License (CC BY-NC) (http://www.karger.com/Services/OpenAccessLicense), applicable to the online version of the article only. Usage and distribution for commercial purposes requires written permission.
Correspondence to:

Carina Leal, carina.leal@chleiria.min-saude.pt 


\section{Adequabilidade das indicações para procedimentos} endoscópicos: um estudo prospetivo e multicêntrico

\section{Palavras Chave}

Endoscopia digestiva $\cdot$ Adequabilidade $\cdot$ Sistemas de acesso livre · Indicações · Sobreuso

\section{Resumo}

Introdução: O avanço em endoscopia digestiva e a existência de sistemas open-acess levaram a um aumento quantitativo de endoscopias. Porém, a sobreutilização da endoscopia tem sido reportada na literatura. Este estudo tem como objetivo aferir prospectivamente as indicações para endoscopia digestiva alta (EDA) e endoscopia digestiva baixa (EDB) em unidades de saúde públicas e privadas. Doentes e métodos: Estudo prospetivo, multicêntrico, que incluiu doentes submetidos a endoscopia digestiva alta (EDA) ou baixa (EDB) com intuito não terapêutico em 2 unidades hospitalares públicas e 5 unidades privadas. Adequabilidade da indicação definida pelas recomendações da American Society for Gastrointestinal Endoscopy (EDA) e do European Panel on Appropriateness of Gastrointestinal Endoscopy II (EDB). Resultados: EDA: Incluídos 215 doentes (masculino - 43.7\%; idade média - $61.0 \pm 15.11$ anos), $54.0 \%$ ( $n=116)$ em unidades hospitalares públicas. Referenciação por gastrenterologista em 34.9\% $(n=75)$. Indicação considerada adequada em $62.3 \%(n=134)$ : $42.4 \%$ em unidades privadas versus $79.3 \%$ em unidades públicas (odds ratio [OR] 5.20,95\% confidence interval [Cl] $2.85-9.49, p<0.01$ ). Indicação adequada em $74.7 \%$ com referenciação por gastrenterologista versus $56.1 \%$ por não-gastrenterologista (OR 2.31, 95\% Cl 1.24-4.28; $p<$ 0.01 ). Identificados achados endoscópicos relevantes em 47.9\%. EDB: Incluídos 287 doentes (masculino - 49.1\%; idade média - $60.4 \pm 14.4$ anos), $48,1 \%(n=138)$ em unidades públicas. Referenciação por gastrenterologista em $20.6 \%(n=59)$. A indicação foi considerada adequada em $70.0 \%$ ( $n=201): 53.0 \%$ em unidade privada versus $88.4 \%$ em unidade pública (OR 6.75, 95\% Cl 3.66-12.47; $p<0.01$ ). Achados endoscópicos relevantes em 57.1\%: 77.7\% ( $n=$ $129)$ em exames com indicação adequada vs $22.3 \%(n=37)$ sem indicação adequada $(p<0.05)$. Conclusões: Neste estudo, uma percentagem significativa dos procedimentos endoscópicos foi realizada sem indicação apropriada, especialmente no sector privado, o que influenciou a rentabilidade diagnóstica. A prescrição tendo por base critérios definidos é fundamental para o uso racional de um sistema de acesso livre.

(c) 2021 Sociedade Portuguesa de Gastrenterologia Publicado por S. Karger AG, Basel

\section{Introduction}

In the last decades, endoscopy has established its position as an essential procedure for the diagnosis, management, and follow-up of multiple benign, premalignant, and malignant diseases. This has led to an increase in the demand for both esophagogastroduodenoscopy (EGD) and colonoscopy $[1,2]$. In Portugal, as in many European and North American countries, an open-access system allows referral for endoscopic procedures without the need for prior consultation [3]. Endoscopies are performed either in the public or private setting; in the latter, referral can be made through public or private healthcare subsystems. The goal of this strategy is to avoid unnecessary consultations and minimize waiting lists, but it is not without costs and harm [4]. In fact, concerns regarding inappropriate referrals and the overuse of endoscopy have been raised [5-13]. A 2010 meta-analysis regarding EGDs reported 22\% inappropriate referrals [14]. Later studies by Crouwel et al. [15], Abdulrahman et al. [16], and Mangualde et al. [17] reported similar outcomes. Regarding colonoscopy, Gimeno-García and Quintero [18] reported only $75.4 \%$ of colonoscopy referrals as appropriate. The appropriateness of the indications can be established through various guidelines; the American Society for Gastrointestinal Endoscopy (ASGE) has issued guidelines on appropriate use of gastrointestinal endoscopy [19] and the European Panel on the Appropriateness of Gastrointestinal Endoscopy II (EPAGE II) on the appropriate use of colonoscopy [20]. Of note, most studies report tertiary single-center results.

The aim of this multicenter study was to prospectively evaluate the appropriateness of EGD and colonoscopy referral in private and public settings. Secondary end points were the suitability of referral according to the medical specialty and the diagnostic yield of the procedures.

\section{Materials and Methods}

This was a cross-sectional study of patients undergoing elective EGD or colonoscopy at 1 tertiary-referral public hospital, 1 secondary-referral public hospital, and 5 private endoscopy units. Patients aged $\geq 18$ years and scheduled for an EGD or colonoscopy without therapeutic intent were consecutively included. Patients unable to consent or submitted to urgent procedures were excluded. Endoscopic examinations were performed by trained gastroenterologists. Prior to the examination, data such as demographic characteristics, information on previous endoscopies, medical therapy, and alarming features (unexplained weight loss, suspected gastrointestinal bleeding, dysphagia, persistent vomiting, detection of an abdominal mass) as well as an indication, were

Leal/Almeida/Silva/Santos/Vasconcelos/ Figueiredo 
Table 1. Demographic and clinical characteristics of the study population

\begin{tabular}{lrr}
\hline & \multicolumn{1}{c}{ EGD } & Colonoscopy \\
\hline Male gender & $94(43.7)$ & $141(49.1)$ \\
Mean age, years (SD) & $61.0(15.1)$ & $60.4(14.4)$ \\
Age $\geq 50$ years & $164(76.3)$ & $225(78.4)$ \\
Referral by gastroenterologist & $75(34.9)$ & $59(20.6)$ \\
Alarming features & $37(17.2)$ & $41(14.3)$ \\
First endoscopy & $81(37.7)$ & $117(40.8)$ \\
Endoscopy performed in the & & \\
$\quad$ public setting & $116(54.0)$ & $138(48.1)$ \\
\hline
\end{tabular}

Values express $n$ (\%), unless otherwise indicated.

collected. Indication was determined according to the information available on the referral form, or, when this was unavailable, by the endoscopist after an interview with the patient. Before performing the examination, endoscopists were asked to answer whether they thought the referral was appropriate. After the examination, endoscopic findings were recorded. Findings were defined as relevant if they had the potential to impact on the patient's management. Indications were reviewed by the investigators. Appropriateness of EGD was defined by the ASGE 2012 guidelines [11] and appropriateness of colonoscopy was defined by the EPAGE II criteria (appropriate/nonappropriate) [12]. The collected data were analyzed using the Statistical Package for the Social Sciences (SPSS) v23, with a significance level set at $p<0.05$. The $\chi^{2}$ and Fisher exact tests were used to find significant associations between qualitative variables. Odds ratios (ORs) and related 95\% confidence intervals (CIs) were used to express the extent of the associations found.

\section{Results}

\section{Esophagogastroduodenoscopy}

Baseline Characteristics

Two hundred and fifteen patients were included in the analysis (Table 1). EGD was performed at public hospitals in $54.0 \%(n=116)$ and at private units in $46.0 \%(n=99)$. Referral for EGD was made by gastroenterologists in $34.9 \%(n=75)$ and by other clinicians in $65.1 \%(n=140)$ patients. The mean age was $61.0( \pm 15.1)$ years and $43.7 \%$ were male. Alarming features were present in $17.2 \%$ patients. At the time of the examination, $13 \%(n=28)$ of the patients were on nonsteroidal anti-inflammatory drugs, $16.3 \%(n=35)$ were smokers, and $40.9 \%(n=88)$ were on proton-pump inhibitors. In $37.7 \%(n=81)$ of the patients, it was the first EGD to be performed.

Appropriateness of Endoscopic

Procedures
Indications and Findings

The indications for EGD are summarized in Table 2. Gastroenterologists performing the EGD deemed the indication to be correct in $81.4 \%(n=175)$ of cases. However, review of indications by investigators confirmed that this was according to ASGE criteria in 62.3\% $(n=$ $134)$. The rate of appropriate referral was $42.4 \%(n=91)$ at private units and $79.3 \%(n=124)$ at public hospitals (OR 5.20; 95\% CI 2.85-9.49; $p<0.01$ ). A statistically significant difference was also found in the rate of appropriate referral for gastroenterologists $(74.7 \%)$ versus other clinicians (56.1\%) (OR 2.31, 95\% CI 1.24-4.28; $p<0.01$ ). Appropriateness of referral was $65.9 \%$ for patients aged $\geq 50$ years and $51.0 \%$ for patients aged $<50$ years $(p=0.06$; Table 3).

The main appropriate indications were upper abdominal symptoms associated with symptoms or signs suggesting organic disease or new-onset symptoms in patients $>50$ years $(22.0 \%$ of the appropriate indications, $n=29)$, surveillance in premalignant conditions $(16.7 \%$, $n=22$ ), and diseases in which the presence of upper gastrointestinal (GI) pathology might modify other planned management $(12.1 \%, n=16)$.

Indications not fitting the ASGE appropriateness criteria were classified as inadequate. The main nonappropriate criteria as clearly set by the ASGE were symptoms considered to be functional (32.1\% of the nonappropriate indications, $n=26$ ). The remaining exams without appropriate criteria were reviewed and the main indication was screening for malignancy in asymptomatic patients without known premalignant conditions $(14.8 \%, n=12)$. Of note, 9.8\% $(n=21)$ EGDs had no written indication on the referral form.

One hundred and twenty-seven relevant endoscopic findings were reported (Table 4). A relevant endoscopic finding was present in $47.9 \%(n=103)$ of the patients. The most common findings were erosive esophagitis and gastritis. Overall, the diagnostic yield for relevant lesions was $34.0 \%$ for EGDs with an appropriate indication and $66.0 \%$ for EGDs without an appropriate indication. This difference did not reach statistical significance $(p=0.88)$. Also, no association was found between the presence of alarming features and relevant endoscopic findings $(p=0.3)$, or between referral by a gastroenterologist and relevant endoscopic findings $(p=1.0)$.

\section{Colonoscopy}

Baseline Characteristics

Two hundred and eighty-seven patients were included in the analysis. Their mean age was $60.4 \pm 14.4$ years and 
Table 2. Referral indications for EGD according to ASGE criteria

\section{Appropriate indications}

$134(62.3 \%)$

Upper abdominal symptoms associated with other symptoms or signs suggesting structural disease or new-onset symptoms in patients aged $>50$ years

Surveillance for malignancy in patients with premalignant conditions

Other diseases in which the presence of upper GI pathology might modify other planned management

Selected patients with suspected portal hypertension to document or treat esophageal varices

GI bleeding

Upper abdominal symptoms that persist despite an appropriate trial of therapy

When sampling of tissue or fluid is indicated

Dysphagia or odynophagia

For confirmation and specific histologic diagnosis of radiologically demonstrated lesions

To assess diarrhea in patients suspected of having small-bowel disease

Esophageal reflux symptoms that persist or recur despite appropriate therapy

Persistent vomiting of unknown cause

SUBTOTAL

Nonappropriate indications

Symptoms considered to be functional

Surveillance for malignancy in patients with gastric atrophy, pernicious anemia, fundic gland or hyperplastic polyps, gastric intestinal metaplasia, or previous gastric operations for benign disease

\section{Miscellaneous}

Screening in asymptomatic patients

Miscellaneous symptoms

Routine in asymptomatic patients

Confirmation of Helicobacter pylori eradication

Surveillance of healed benign disease, such as esophagitis and gastric or duodenal ulcer

Asymptomatic or uncomplicated sliding hiatal hernia

29

22

16

15

11

10

8

6

5

132

$81(37.7 \%)$

26

17

(6)

2

1

(37.7\%)

7


Table 4. EGD findings according to the appropriateness of the indication

\begin{tabular}{lcc}
\hline & $\begin{array}{l}\text { Nonappropriate, } \\
n(\%)\end{array}$ & $\begin{array}{l}\text { Appropriate, } \\
(\%)\end{array}$ \\
\hline Relevant findings & & \\
Angioectasia & $0(0.0)$ & $2(1.1)$ \\
Esophageal candidiasis & $1(1.0)$ & $1(0.6)$ \\
Foreign body & $1(1.0)$ & $1(0.6)$ \\
Diverticulum & $0(0.0)$ & $3(1.7)$ \\
Duodenopathy - erosive & $3(3.0)$ & $5(2.8)$ \\
Reflux esophagitis & $11(11.1)$ & $11(6.1)$ \\
Other esophagitis & $0(0.0)$ & $3(1.7)$ \\
Barrett's esophagus & $0(0.0)$ & $3(1.7)$ \\
Benign stricture & $0(0.0)$ & $1(0.6)$ \\
Malignant stricture & $1(1.0)$ & $0(0.0)$ \\
Gastropathy & & \\
$\quad$ Erosive & $8(8.1)$ & $17(9.5)$ \\
$\quad$ Portal hypertensive & $0(0.0)$ & $1(0.6)$ \\
Submucosal lesion & $2(2.0)$ & $5(2.8)$ \\
Gastric cancer & $1(1.0)$ & $2(1.1)$ \\
Polyp & $8(8.1)$ & $8(4.5)$ \\
Ulcer & $0(0.0)$ & $11(6.1)$ \\
Gastroesophageal varices & $1(1.0)$ & $8(4.5)$ \\
Miscellaneous & $1(1.0)$ & $7(3.9)$ \\
\hline Other findings & $3(3.0)$ & $5(2.8)$ \\
Gastric postoperative appearance & \\
Gastropathy & & \\
$\quad$ Nonerosive & $25(25.3)$ & $10(5.6)$ \\
Hiatus hernia & $11(11.1)$ & \\
Normal & $22(22.2)$ & $(100.1)$ \\
\hline Total & $99(100.0)$ & \\
\hline & & \\
\hline
\end{tabular}

$49.1 \%$ were male. Colonoscopies were performed at public hospitals in $48.1 \%(n=138)$ and at private endoscopy units in $52.9 \%(n=149)$. Referral was made by a gastroenterologist in 20.6\% $(n=59)$ cases. Alarming features were present in $14.3 \%(n=41)$ of the patients. The majority of the study population, i.e., $59.2 \%(n=170)$, had already been submitted to a colonoscopy $4.2 \pm 3.7$ years previously. Regarding previous colonoscopies, information on bowel preparation and visualization of the entire colon was available in $94.7 \%(n=161)$, with bowel preparation classified as adequate in $71.4 \%(n=115)$ and colonoscopy in $83.9 \%(n=135)$.

\section{Indications and Findings}

The indications for colonoscopy are summarized in Table 5. Endoscopists considered indications to be appropriate in $87.8 \%(n=252)$ of the cases. However, when EPAGE II criteria were applied, the rate of adequate indi- cation decreased to $70.0 \%$ ( $n=201 ; 53.0 \%$ for private units and $88.4 \%$ for public hospitals [OR 6.75 ; 95\% CI $3.66-12.47 ; p<0.01])$. Appropriateness of referral was $79.7 \%$ by the gastroenterologist and $67.4 \%$ by other clinicians $(p=0.08)$. Appropriateness of referral was $78.2 \%$ for patients aged $\geq 50$ years and $40.3 \%$ for patients aged $<50$ years (OR 5.31; 95\% CI 2.92-9.67; $p<0.01$; Table 3 ).

The main appropriate indications were screening for colorectal cancer $(33.3 \%$ of the appropriate indications, $n=67$ ) and surveillance colonoscopy after colorectal cancer resection or polypectomy $(23.9 \%, n=48)$. According to the EPAGE II criteria, the most common nonappropriate criterion was surveillance colonoscopy after polypectomy. Of the $30.0 \%(n=86)$ of nonappropriate indications, $36.0 \%(n=31)$ were classified as uncertain.

\section{Endoscopic Findings}

Endoscopic findings are summarized in Table 6. Relevant endoscopic findings were present in 57.1\% $(n=$ $164)$ of the colonoscopies and $32.1 \%(n=92)$ were normal. The most common relevant endoscopic diagnosis was colonic polyps.

Relevant endoscopic diagnosis was associated with the appropriateness of the indication: $63.2 \%$ in the appropriate indication group compared to $43.0 \%(n=37)$ in the nonappropriate indication group $(p<0.05)$. No significant association was found between referral by gastroenterologist and relevant endoscopic findings $(p=0.1)$. No association was found between the presence of alarming features and relevant endoscopic findings $(p=0.6)$.

\section{Discussion}

Our era has been called the "golden age of endoscopy," as this resource is now readily available to most patients and clinicians in developed nations [4]. Endoscopy is regarded as a safe, informative, and potentially curative procedure. However, many authors have raised concerns about the overuse and inappropriate use of endoscopy.

Our data on appropriateness of EGD show up to $38.7 \%$ procedures without an appropriate indication according to the ASGE and EPAGE criteria, in line with previous reports. These high rates may be explained by a myriad of factors: patient-related (a desire for screening or surveillance programs), clinician-related (the fear of watchful waiting and malpractice litigation, under appreciation of adverse events, and awareness of the endoscopy potential), and system-related (unavailable medical records and monetary compensation). We hypothesize that such 
Table 5. Referral indications for colonoscopy according to EPAGE II criteria

\begin{tabular}{|c|c|}
\hline & $N=287$ \\
\hline Appropriate indications & $201(70.0 \%)$ \\
\hline Colorectal cancer screening & 67 \\
\hline Surveillance colonoscopy after polypectomy; follow-up colonoscopy & 24 \\
\hline Surveillance colonoscopy after colorectal cancer resection & 24 \\
\hline Miscellaneous & 22 \\
\hline Iron deficiency anemia & 15 \\
\hline Colorectal cancer screening in patients with known IBD & 15 \\
\hline $\begin{array}{l}\text { Lower abdominal symptoms of at least } 3 \text { months duration, with no alarming features or known } \\
\text { IBD }\end{array}$ & 13 \\
\hline Hematochezia without hemodynamic instability & 9 \\
\hline Assessment of ulcerative colitis, excluding cancer surveillance & 5 \\
\hline Uncomplicated chronic diarrhea & 4 \\
\hline Assessment of Crohn's disease, excluding cancer surveillance & 3 \\
\hline Nonappropriate indications & $86(30.0 \%)$ \\
\hline Surveillance colonoscopy after polypectomy; follow-up colonoscopy & 21 \\
\hline Colorectal cancer screening & 20 \\
\hline $\begin{array}{l}\text { Lower abdominal symptoms of at least } 3 \text { months duration, with no alarming features or known } \\
\text { IBD }\end{array}$ & 17 \\
\hline Miscellaneous & 12 \\
\hline Hematochezia without hemodynamic instability & 9 \\
\hline Uncomplicated chronic diarrhoea & 3 \\
\hline Assessment of ulcerative colitis, excluding cancer surveillance & 1 \\
\hline Assessment of Crohn disease, excluding cancer surveillance & 1 \\
\hline Colorectal cancer screening in patients with known IBD & 1 \\
\hline Iron deficiency anemia & 1 \\
\hline Surveillance colonoscopy after colorectal cancer resection & 0 \\
\hline
\end{tabular}

factors as well as an endoscopy-driven reasoning, particularly nonadherence to the guidelines, may explain the greater proportion of EGDs considered by gastroenterologists as appropriate. We should also emphasize that an observer bias could not be totally ruled out, and, most importantly, it is arguable whether these international guidelines can be universally applied to all countries. In fact, each country has some specificities, and the accuracy of such guidelines could not be optimized [21].

In our study, the odds of appropriate referral were higher in the public setting than in the private units. Re- ferral for private units was mainly through public healthcare subsystems. These findings could reflect the nonadherence to ASGE guidelines by nongastroenterologists but also the differences in the referral process. In fact, in public hospitals, all requests are subjected to a thorough triage process, but this does not happen in the private setting since the gastroenterologist has access to the referral just before the endoscopic procedure. Of concern, 21 referrals had no written information. This is not acceptable, and the prescription process should automatically be blocked if no information is available.
Leal/Almeida/Silva/Santos/Vasconcelos/ Figueiredo 
Table 6. Colonoscopy findings according to appropriateness of the indication

\begin{tabular}{lcc}
\hline & $\begin{array}{l}\text { Nonappropriate, } \\
n(\%)\end{array}$ & $\begin{array}{l}\text { Appropriate, } \\
n(\%)\end{array}$ \\
\hline $\begin{array}{l}\text { Relevant findings } \\
\text { Angioectasia }\end{array}$ & & \\
Ulcerative colitis & $0(0.0)$ & $7(2.8)$ \\
$\quad$ Active & $0(0.0)$ & $7(2.8)$ \\
$\quad$ Quiescent & $1(1.0)$ & $5(2.0)$ \\
Crohn's disease & & \\
$\quad$ Active & $0(0.0)$ & $5(2.0)$ \\
Quiescent & $0(0.0)$ & $1(0.4)$ \\
Submucosal lesion & $2(2.1)$ & $3(1.2)$ \\
Colorectal cancer & $0(0.0)$ & $6(2.4)$ \\
Polyp & & $62(24.9)$ \\
$\quad$ Size $\leq 5$ mm & $20(20.6)$ & $31(12.4)$ \\
Size $>5$ mm & $9(9.3)$ & $11(4.4)$ \\
Unclassified & $11(11.3)$ & $1(0.4)$ \\
Solitary ulcer & $0(0.0)$ & $8(3.2)$ \\
Miscellaneous & $1(1.0)$ & $26(10.4)$ \\
\hline Other findings & & $1(0.4)$ \\
$\quad$ Diverticulosis & $12(12.4)$ & $52(20.9)$ \\
Melanosis & $1(1.0)$ & \\
Postoperative appearance & $0(0.0)$ & $(100.0)$ \\
Normal & $40(41.2)$ & \\
\hline Total & $97(100.0)$ & \\
\hline
\end{tabular}

Observational studies have raised questions about the validity of the ASGE guidelines in identifying relevant endoscopic diagnoses. In our study, the diagnostic yield of these guidelines for relevant findings was indeed disappointing. Also, a significant proportion of relevant findings was found in exams without an appropriate indication. Buri et al. [22] propose simpler, symptom-based criteria. However, in our study, neither the presence of alarming features nor the endoscopist's view on the appropriateness of the indication were associated with a relevant endoscopic diagnosis. This said, it should be noted that EGDs without relevant findings may actually improve the clinician's diagnostic yield. Ultimately, and since most of the referrals come from primary care physicians or other specialties, defined criteria as opposed to clinical reasoning may be important in the management of resources [23]. A previous study has already challenged the accuracy of previous ASGE indications for EGD in Portugal. Developing national prescription guidelines would likely result in better outcomes. The importance of nationwide validation of such guidelines cannot be stressed enough, as the strict use of international criteria may ultimately result in an underdiagnosis of GI diseases. Such recommendations would have to be broadly publicized acrossall medical specialties, so as to minimize inappropriate referrals for endoscopic procedures.

For example, a significant proportion of patients was doing the EGD as a form of gastric cancer screening. While it is true that such a screening program is not a reality in our country, these findings probably reflect clinicians' and patients' awareness of the high rates of gastric cancer in Portugal and the need to discuss the implementation of such a program [24].

Regarding colonoscopies, $30.0 \%$ of the indications were classified as nonappropriate (including inappropriate and uncertain indications). The prevalence of inflammatory bowel disease in the study population reflects the nature of the hospitals. As with EGD, the odds of appropriate referral were significantly higher in the public setting than in private units and considered to be of clinical importance. An important percentage of the nonappropriate indications $(48.8 \%)$ concerned surveillance and screening programs. It should also be stressed that key performance measures for colonoscopy were suboptimal, as the global rate of both adequate bowel preparation and cecal intubation was $<90 \%$. Importantly, no colorectal cancer was identified in the nonappropriate colonoscopy indication group. Early repetition of colonoscopy is welldocumented in the literature. While it is true that evidence of optimal screening time is limited, gastroenterologist's opinion on screening intervals, multiplicity of recommendations, and a patient's wishes may ultimately lead to these findings. As the workload and the pressure on both public and private health systems increases, and since colonoscopy is not without risks, the ongoing discussion on surveillance programs and quality measures in colonoscopy seems to be essential. This is of paramount importance in the period since the COVID-19 pandemic, as there has been a decrease in the response capabilities of endoscopy units, and a correct triage of procedures is a priority to be able to perform procedures deemed as necessary. A multidisciplinary discussion is urgently needed to establish clear referral criteria and correct use of health resources. Strategies like "Choosing Wisely" must be optimized and publicized for clinicians to have correct information about the appropriate indications for endoscopic procedures.

In conclusion, we believe this study is significant as it portrays the current situation in an open-access system supported by both public and private healthcare units. Although a significant number of endoscopic procedures have an appropriate indication, there is room for further 
improvement. The pressure with which the system is faced nowadays has made it imperative to guide our practice by the medical standard of care. Endoscopy has proven to be a fundamental aid in the diagnosis of digestive diseases, and it will reach its full potential when referral is appropriate.

\section{Acknowledgment}

We wish to thank all medical doctors, nurses, and technical assistants at the involved endoscopy units for their invaluable help during data acquisition.

\section{Statement of Ethics}

The subjects have given their written informed consent and the study protocol was approved by the institute's committee on human research and it conforms to the ethics guidelines of the 1975 Declaration of Helsinki.

\section{Conflict of Interest Statement}

The authors have no conflicts of interest to declare.

\section{Funding Sources}

There was no funding.

\section{References}

1 Peery AF, Crockett SD, Murphy CC, Lund JL, Dellon ES, Williams JL, et al. Burden and cost of gastrointestinal, liver, and pancreatic diseases in the United States: update 2018. Gastroenterology. 2019 Jan;156(1):254-72.e11.

2 Seeff LC, Richards TB, Shapiro JA, Nadel MR, Manninen DL, Given LS, et al. How many endoscopies are performed for colorectal cancer screening? Results from CDC's survey of endoscopic capacity. Gastroenterology. 2004 Dec;127(6):1670-7.

3 Chandrasekhara V, Eloubeidi MA, Bruining DH, Chathadi K, Faulx AL, Fonkalsrud L, et al.; ASGE Standards of Practice Committee. Open-access endoscopy. Gastrointest Endosc. 2015;81(6):1326-9.

4 Shaheen NJ, Fennerty MB, Bergman JJ. Less is more: a minimalist approach to endoscopy. Gastroenterology. 2018 May;154(7):19932003.

5 Rajan S, Amaranathan A, Lakshminarayanan S, Sureshkumar S, Joseph M, Nelamangala Ramakrishnaiah VP. Appropriateness of American Society for Gastrointestinal Endoscopy Guidelines for Upper Gastrointestinal Endoscopy: A Prospective Analytical Study. Cureus. 2019 Feb;11(2):e4062.

6 Argüello L, Pertejo V, Ponce M, Peiró S, Garrigues $\mathrm{V}$, Ponce $\mathrm{J}$. The appropriateness of colonoscopies at a teaching hospital: magnitude, associated factors, and comparison of EPAGE and EPAGE-II criteria. Gastrointest Endosc. 2012 Jan;75(1):138-45.

7 Gimeno García AZ, González Y, Quintero E, Nicolás-Pérez D, Adrián Z, Romero R, et al. Clinical validation of the European Panel on the Appropriateness of Gastrointestinal Endoscopy (EPAGE) II criteria in an open-access unit: a prospective study. Endoscopy. 2012 Jan;44(1):32-7.
8 Carrión S, Marín I, Lorenzo-Zúñiga V, Moreno De Vega V, Boix J. [Appropriateness of colonoscopy indications according to the new EPAGE II criteria]. Gastroenterol Hepatol. 2010 Aug-Sep;33(7):484-9.

9 Eskeland SL, Dalén E, Sponheim J, Lind E, Brunborg C, de Lange T. European panel on the appropriateness of gastrointestinal endoscopy II guidelines help in selecting and prioritizing patients referred to colonoscopy-a quality control study. Scand J Gastroenterol. 2014 Apr;49(4):492-500.

10 Goodwin JS, Singh A, Reddy N, Riall TS, Kuo YF. Overuse of screening colonoscopy in the Medicare population. Arch Intern Med. 2011 Aug;171(15):1335-43.

11 Grassini M, Verna C, Niola P, Navino M, Battaglia E, Bassotti G. Appropriateness of colonoscopy: diagnostic yield and safety in guidelines. World J Gastroenterol. 2007 Mar;13(12):1816-9.

12 Hassan C, Bersani G, Buri L, Zullo A, Anti M, Bianco MA, et al. Appropriateness of upperGI endoscopy: an Italian survey on behalf of the Italian Society of Digestive Endoscopy. Gastrointest Endosc. 2007 May;65(6):767-74.

13 Kruse GR, Khan SM, Zaslavsky AM, Ayanian JZ, Sequist TD. Overuse of colonoscopy for colorectal cancer screening and surveillance. J Gen Intern Med. 2015 Mar;30(3):277-83.

14 Di Giulio E, Hassan C, Marmo R, Zullo A, Annibale B. Appropriateness of the indication for upper endoscopy: a meta-analysis. Dig Liver Dis. 2010 Feb;42(2):122-6.

15 Crouwel F, Meurs-Szojda MM, Klemt-Kropp M, Fockens P, Grasman ME. The diagnostic yield of open-access endoscopy of the upper gastrointestinal tract in the Netherlands. Endosc Int Open. 2018 Apr;6(4):E383-94.

16 Abdulrahman AM, Alswat K, Almadi MA. Appropriateness and diagnostic yield of upper gastrointestinal endoscopy in an openaccess endoscopy system. Saudi J Gastroenterol. 2013 Sep-Oct;19(5):219-22.
17 Mangualde J, Cremers MI, Vieira AM, Freire R, Gamito E, Lobato C, et al. Appropriateness of outpatient gastrointestinal endoscopy in a non-academic hospital. World J Gastrointest Endosc. 2011 Oct;3(10):195-200.

18 Gimeno-García AZ, Quintero E. Colonoscopy appropriateness: really needed or a waste of time? World J Gastrointest Endosc. 2015 Feb;7(2):94-101.

19 Early DS, Ben-Menachem T, Decker GA, Evans JA, Fanelli RD, Fisher DA, et al.; ASGE Standards of Practice Committee. Appropriate use of GI endoscopy. Gastrointest Endosc. 2012 Jun;75(6):1127-31.

20 Juillerat P, Peytremann-Bridevaux I, Vader JP, Arditi C, Schusselé Filliettaz S, Dubois RW, et al. Appropriateness of colonoscopy in Europe (EPAGE II). Presentation of methodology, general results, and analysis of complications. Endoscopy. 2009 Mar;41(3):240-6.

21 Cerqueira R, Fernandes C, Correia M, Manso MC. Indications for upper gastrointestinal endoscopy. The accuracy of the American Society for Gastrointestinal Endoscopy guidelines in a Portuguese hospital. Acta Med Port. 2008 Sep-Oct;21(5):427-32.

22 Buri L, Hassan C, Bersani G, Anti M, Bianco MA, Cipolletta L, et al.; SIED Appropriateness Working Group. Appropriateness guidelines and predictive rules to select patients for upper endoscopy: a nationwide multicenter study. Am J Gastroenterol. 2010 Jun;105(6):1327-37.

23 de Jong JJ, Lantinga MA, Drenth JP. Prevention of overuse: A view on upper gastrointestinal endoscopy. World J Gastroenterol. 2019 Jan;25(2):178-89.

24 Areia M, Spaander MC, Kuipers EJ, DinisRibeiro M. Endoscopic screening for gastric cancer: A cost-utility analysis for countries with an intermediate gastric cancer risk. United European Gastroenterol J. 2018 Mar;6(2):192-202. 